\title{
Accumulation of steroids in rabbit preimplantation blastocysts
}

\author{
R. M. Borland, G. F. Erickson* and T. Ducibella \\ Departments of Physiology, Obstetrics and Gynecology, and Anatomy, \\ Laboratory of Human Reproduction and Reproductive Biology, \\ Harvard Medical School, Boston, Massachusetts 02115, U.S.A.
}

\begin{abstract}
Summary. The concentrations of progesterone, androstenedione, testosterone, oestrone and oestradiol were measured by radioimmunoassay in blastocysts and uterine fluid flushings collected from rabbits 110 to $159 \mathrm{~h}$ post coitum (p.c.). None of the blastocysts or uterine flushings contained detectable levels of androstenedione, testosterone or oestrone. All uterine flushings contained large amounts of progesterone and some of the flushings also contained oestradiol.

A small amount of progesterone $(\sim 7.5 \mathrm{pg} /$ blastocyst $)$ was first detectable in some blastocysts at $135 \mathrm{~h}$ p.c.; progesterone levels/blastocyst then increased progressively, reaching levels of about $122-158 \mathrm{pg} /$ blastocyst at $159 \mathrm{~h} \mathrm{p.c.} \mathrm{Micropuncture} \mathrm{of}$ blastocysts at $159 \mathrm{~h}$ p.c. indicated that $\geqslant 90 \%$ of the progesterone in the embryo was in the blastocoelic fluid. Blastocysts from rabbit uterine horns containing oestradiol also contained oestradiol but those in which oestradiol was detected were never observed in uteri lacking the hormone. It is inferred that rabbit blastocysts accumulate both progesterone and oestradiol from uterine fluid.
\end{abstract}

\section{Introduction}

A recent histochemical study by Dickmann, Dey \& Gupta (1975) demonstrated the presence of both $\Delta^{5}, 3 \beta$-hydroxysteroid dehydrogenase $\left(\Delta^{5}, 3 \beta-H S D\right)$ and $17 \beta$-hydroxysteroid dehydrogenase (17 $\beta$-HSD) activities in 6-day rabbit blastocysts. The authors suggested that blastocysts of this age have the enzymatic capacity to synthesize progesterone, oestrogens and perhaps androgens because these enzymes convert pregnenolone to progesterone $\left(\Delta^{5}, 3 \beta-H S D\right)$ and oestrone to oestradiol-17 $\beta$ and androstenedione to testosterone (17 $\beta$-HSD). Huff \& Eik-Nes (1966) demonstrated that 6-day post coitum (p.c.) rabbit blastocysts incubated for 24-96 h can synthesize cholesterol and pregnenolone from acetate and convert progesterone to $5 \beta$-pregnanedione and $20 \alpha$-hydroxypregn-4-en3-one, although the ability of the embryo to metabolize steroids remained constant over a 4-day period and there was no correlation between the amount of steroid transformation and the number of blastocysts. Huff \& Eik-Ness (1966) were unable to identify progesterone or oestrogens when embryos were incubated with pregnenolone or androstenedione, respectively.

Other investigators, using competitive protein binding assays, have found significant concentrations of progesterone in rabbit uterine fluid and in blastocysts and blastocoele fluid at 5 and 6 days p.c. (Seamark \& Lutwak-Mann, 1972; Fuchs \& Beling, 1974). Seamark \& Lutwak-Mann (1972) suggested that the presence of large amounts of progesterone in uterine fluid could indicate that progesterone is not synthesized by the blastocyst but rather is transferred to them via uterine secretions.

In the present study we measured the amounts of progesterone, androstenedione, testosterone, oestrone and oestradiol in freshly collected rabbit blastocysts, blastocoele fluid and rabbit uterine flushings during the preimplantation period to determine the capacity of embryos to accumulate these steroids.

* Present address: Department of Reproductive Medicine, University of California, San Diego, La Jolla, California 92037, U.S.A. 


\section{Materials and Methods}

\section{Collection of uterine flushings, blastocysts and blastocoele fluid}

New Zealand White rabbits $(3 \cdot 6-4 \cdot 5 \mathrm{~kg})$ were mated naturally and killed at $110,135,140,142 \cdot 5$, 144 and $159 \mathrm{~h}$ p.c. The uterine horns were cannulated at the cervical end and the embryos flushed out of each horn with $10 \mathrm{ml}$ Kreb's-Ringer bicarbonate supplemented with $0.1 \%$ glucose (KRBG). Embryos from each mother were removed from the uterine flushings, washed 4 times with KRBG, placed in glass vials, and stored at $-20^{\circ} \mathrm{C}$ until analysis. At $159 \mathrm{~h}$ p.c. samples of blastocoele fluid were collected by the micropuncture techniques of Borland, Biggers \& Lechene (1976). Samples of blastocoele fluid and uterine flushings were kept frozen in glass vials at $-20^{\circ} \mathrm{C}$ until radioimmunoassay.

\section{Radioimmunoassay}

To each vial containing the blastocysts from a single doe, $1 \mathrm{ml} \mathrm{0} 1 \mathrm{M}$-phosphate buffer was added and the vials frozen and thawed 5 times to ensure breakdown of cell structures. The blastocysts were extracted for $30 \mathrm{~min}$ with $5 \mathrm{ml}$ fresh ethyl ether. After chromatographic separation on microcelite columns, the concentrations of progesterone, androstenedione, testosterone, oestrone and oestradiol were measured by previously described and evaluated radioimmunoassay procedures (Challis, Davies \& Ryan, 1973; Challis, Davies, Benirschke, Hendrickx \& Ryan, 1975). The progesterone anteriserum was kindly donated by $\mathrm{Mr}$ B. Hopper and the oestrogen and testosterone antisera by Dr B. V. Caldwell. Androstenedione was assayed using antibody S-1554 No. 2 supplied by Dr G. Abraham. Antibody S-1554 No. 2 cross-reacted with dehydroepiandrosterone and antiserum to testosterone cross-reacted with $5 \alpha$-dihydrotestosterone, but the chromatographic system used in these studies allowed complete separation of the steroids. The recovery of known amounts of radiolabelled steroids in these systems is reported to be approximately $75 \%$. The sensitivity of all assays was around $10 \mathrm{pg} / \mathrm{ml}$.

\section{Electron microscopy}

Rabbit blastocysts were flushed from the uteri of females at $110,135,144$ and $159 \mathrm{~h} \mathrm{p.c.} \mathrm{with} 1 \%$ paraformaldehyde and $2.5 \%$ glutaraldehyde in $0.1 \mathrm{M}$-cacodylate buffer at $3{ }^{\circ} \mathrm{C}$. After $2 \mathrm{~h}$, embryos were washed in buffer, osmicated in $1 \%$ osmium tetroxide in buffer for $15 \mathrm{~min}$ at $3{ }^{\circ} \mathrm{C}$, washed in buffer again, rapidly dehydrated in a graded series of ethanol, and infiltrated and embedded in Epon-Araldite (Anderson \& Ellis, 1965). Grey to silver sections were obtained with a diamond knife, collected on $3 \%$ formvar-coated 150-mesh grids, and stained for 15-30 sec with uranyl acetate (Watson, 1958) followed by lead (Sato, 1958). Embryos were processed for freeze fracturing as described by Ducibella, Albertini, Anderson \& Biggers (1975).

\section{Results}

\section{Steroids in uterine fluid and blastocysts}

As shown in Table 1, all the uterine fluid flushings contained large amounts of progesterone, some contained oestradiol, but androstenedione, testosterone and oestrone were not detectable ( $<10 \mathrm{pg} /$ uterine horn). Detectable levels of progesterone were first found in blastocysts from one rabbit at $135 \mathrm{~h}$ p.c.; the content then increased with embryonic age. Blastocoele fluid pooled from 19 micropunctured blastocysts $159 \mathrm{~h}$ p.c. contained $\geqslant 90 \%$ of the progesterone in these embryos. It is thus assumed that most of the steroid content of whole blastocysts 110 to $159 \mathrm{~h}$ p.c. is present in the blastocoele fluid. The diameters of blastocysts collected from a number of rabbits were therefore measured with an eye-piece graticule and used to calculate the volume of the embryos, and thence the 


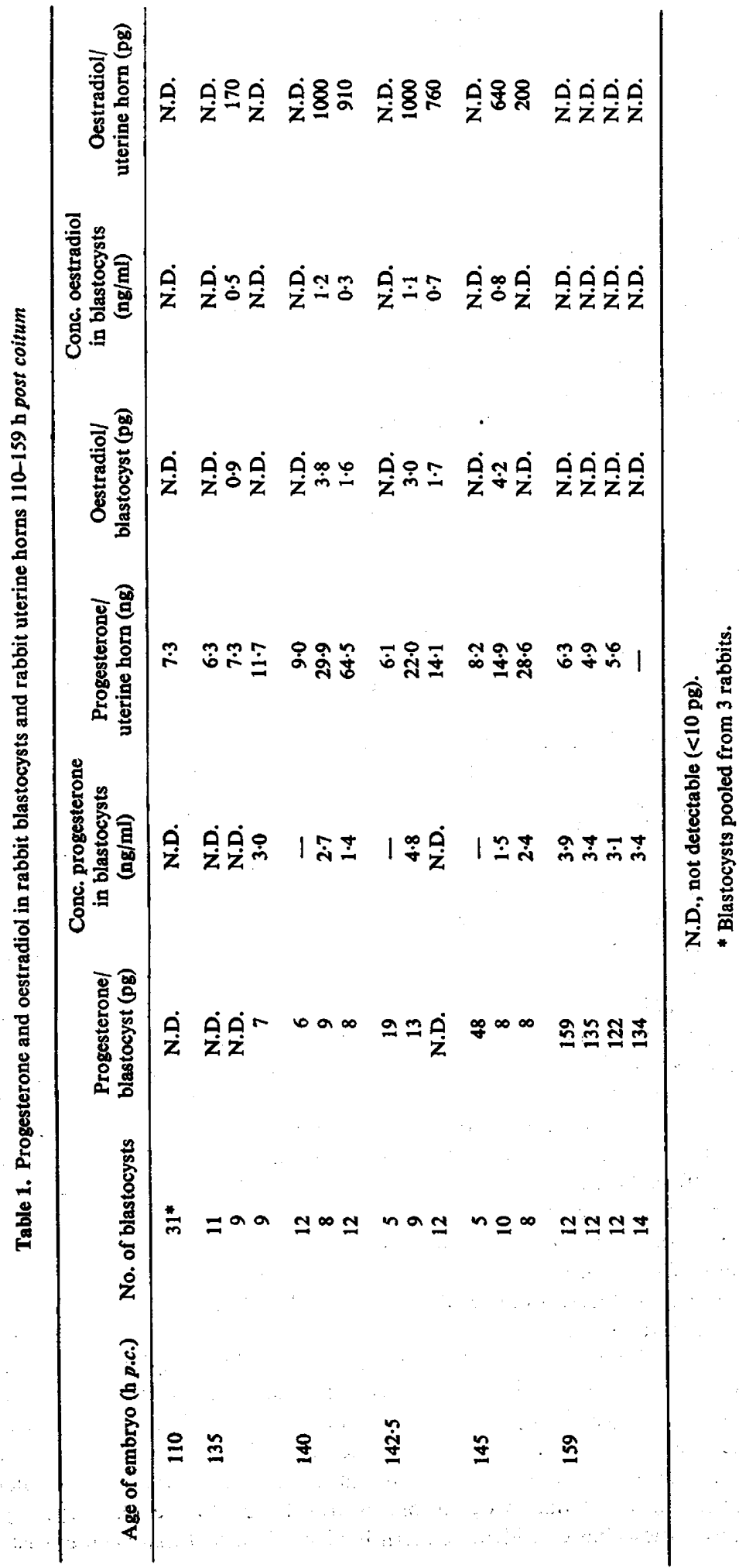


concentration of progesterone in the blastocoele fluid. Excluding the non-detectable samples, the mean \pm S.E.M. progesterone concentration in blastocysts averaged $2.9 \pm 0.3 \mathrm{ng} / \mathrm{ml}$ from $110-159$ h p.c.

Some, but not all, blastocysts contained low but detectable amounts of oestradiol and the mean \pm S.E.M. concentration in the oestradiol-containing blastocysts was $0 \cdot 8 \pm 0 \cdot 1 \mathrm{ng} / \mathrm{ml}$.

\section{Electron microscopy}

Between 110 and $159 \mathrm{~h}$ p.c. the rabbit embryos contained vesicles with a slightly electron-dense, homogeneous substance (Pl. 1, Figs a and b). After freeze fracturing, the contents of these vesicles appeared as smooth, non-particulate concentric layers reminiscent of lipid-containing droplets (Pl. 1, Fig. d). Some vesicles were observed in $110 \mathrm{~h}$ embryos, but at 135 and $144 \mathrm{~h}$ p.c. there were increased numbers of vesicles, often in large clusters (Pl. 1, Fig. a). Some of the clusters faced the blastocoelic surface of the trophoblast and, at later stages, the vesicular contents appeared to be released into the blastocoele (P1. 1, Figs $b$ and $c$ ).

\section{Discussion}

In the present experiments, relatively large amounts of progesterone, and occasionally oestradiol, were observed in rabbit uterine fluid throughout the preimplantation period from 110 to $159 \mathrm{~h} p . c$. The progesterone levels found in the uterine fluid of pregnant rabbits (Table 1) are similar in magnitude to the levels of this steroid found in uterine flushings from rabbits made pseudopregnant by injection of HCG (12-105 ng/uterus) (Fowler, Johnson, Walters \& Pratt, 1976). The high levels of progesterone in uterine fluid may be due to sequestration of the steroid in the uterine lumen from plasma. The uterine protein, uteroglobin, which appears in rabbit uterine fluid at $72 \mathrm{~h} \mathrm{p.c.} \mathrm{and} \mathrm{increases} \mathrm{to} \mathrm{a}$ maximum at $120 \mathrm{~h}$ p.c. (Gulyas \& Krishnan, 1971), has been shown to bind large amounts of progesterone (Beato \& Baier, 1975) and may be involved in such sequestration. However, Rahman, Velayo, Domres \& Billiar (1975) have demonstrated that progesterone is bound to uteroglobin in amounts no greater than that bound to rabbit serum albumin. The relationship of the amount of uteroglobin and the concentration of progesterone in uterine fluid therefore remains uncertain.

The high progesterone and oestradiol concentrations in uterine fluid could also be due to an influx of ovarian steroids into the uterus via the oviducts. On Days 4-6 p.c. rabbit corpora lutea synthesize large amounts of progesterone $(13.7 \mu \mathrm{g} / \mathrm{ovary} / \mathrm{h})$ and smaller amounts of oestradiol $(13.5 \mathrm{ng} / \mathrm{ovary} / \mathrm{h})$ (Hilliard \& Eaton, 1971). Fluid flow from the oviduct into the uterus occurs throughout early pregnancy but is predominant on the 3rd and 4th days post coitum (Hafez, 1963).

Radioimmunoassay of blastocoelic fluid from micropunctured blastocysts suggests that nearly all the progesterone is located in this fluid. Progesterone is not detectable in the blastocyst until 135$140 \mathrm{~h}$ p.c., but it then increases rapidly to a level of $135 \mathrm{pg} /$ blastocyst at $159 \mathrm{~h}$ p.c. Previous reports indicate that rabbit blastocysts at 5-6 days p.c. contain 150-250 pg progesterone(Lutwak-Mann, 1971; Fuchs \& Beling, 1974). These amounts are higher than those reported in Table 1 and may be due either to variation in size of the preimplantation blastocysts or to the use of different assay procedures (competitive protein binding assay or radioimmunoassay).

The low levels of oestradiol found in blastocysts from some rabbits agree with the report of Dickmann et al. (1975) that freshly collected $144 \mathrm{~h}$ p.c. rabbit blastocysts contain very small amounts of oestradiol (0.3-3 pg/blastocyst). This result is consistent with the suggestion by Bhatt \& Bullock (1974) that oestradiol binding to rabbit blastocysts is required for implantation. The failure in the present study to detect androstenedione, testosterone and oestrone in either uterine fluid or blastocysts does not exclude the possibility that these steroids are present in trace amounts.

The progesterone and oestradiol that accumulate in rabbit blastocysts in utero could originate from steroids in the uterine fluid or de novo steroid synthesis by the embryo itself. Seamark \& LutwakMann (1972) have suggested that progesterone is transferred to the blastocyst by endometrial secretions. This hypothesis has considerable merit in view of the fact that (1) the blastocyst expands 
PLATE 1
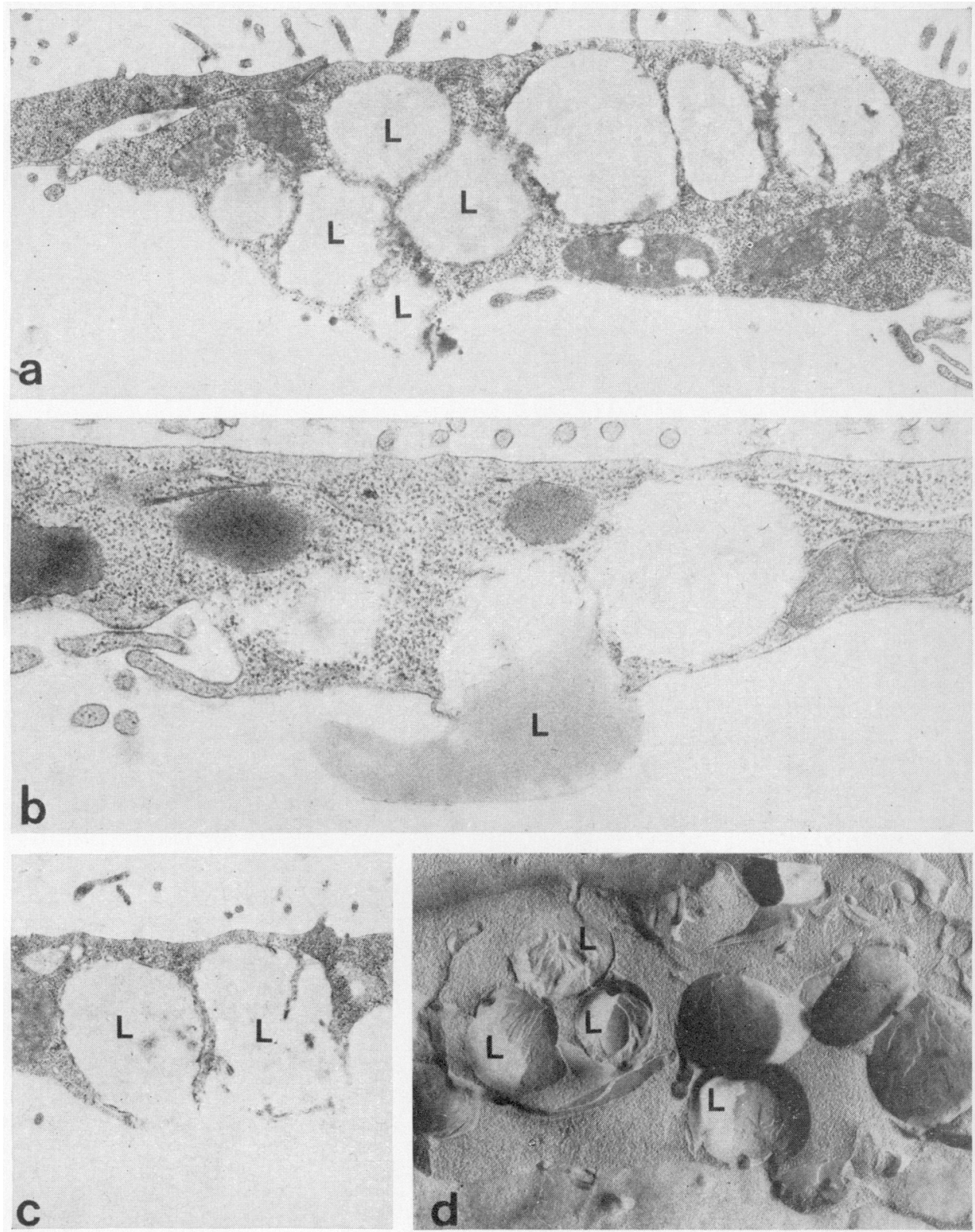

Trophoblast cells from rabbit blastocysis $135-159 \mathrm{~h}$ p.c. The blastocoelic surface of the trophoblast cells is at the lower edge of each micrograph. Figs a-c. Different stages in the release of lipid-like vesicles (L). Fig. a, $\times 13,700$; Fig. b, $\times 28,800$; Fig. c, $\times 12,400$. Fig. d. Freeze-fracture replica demonstrating concentric layering in vesicles $(\mathrm{L}) . \times 19,000$. 
rapidly in uterine fluid which contains high levels of progesterone; (2) rabbit trophoblast cells do not contain the extensive smooth endoplasmic reticulum and tubular mitochondria characteristic of steroid-synthesizing cells; and (3) blastocysts containing oestradiol were never observed in uterine horns lacking this hormone.

Because zonular tight junctions in the trophoblast provide a permeability barrier (Ducibella et al., 1975; Hastings \& Enders, 1975), steroid transport into the blastocoele cavity is most likely via a transcellular route. The rabbit blastocyst exhibits a high degree of selective permeability during the preimplantation period. For example, Hastings \& Enders (1974) demonstrated that rabbit trophoblast cells preferentially endocytose peroxidase and myoglobin (but not ferritin) and that both of these proteins subsequently accumulate in the blastocoele. Accumulation of progesterone in the rabbit blastocyst may be related to the appearance of uteroglobin in the blastocoele fluid. Beier \& Maurer (1975) have suggested that uteroglobin may act as a carrier protein to transport progesterone into the embryo and the uteroglobin-progesterone complex could presumably be transported by pinocytosis as suggested for other proteins (Hastings \& Enders, 1974). Uteroglobin does not appear in blastocoele fluid until $132-140 \mathrm{~h}$ p.c., despite the fact that the protein first appears in rabbit uterine fluid at $72 \mathrm{~h}$ p.c. (Hamana \& Hafez, 1970). The appearance of progesterone in rabbit blastocoele fluid at 135-140 h p.c. (Table 1) correlates well with the first appearance of uteroglobin in the blastocoele and supports the hypothesis that uteroglobin may be a progesterone carrier protein.

Alternatively, the release of lipid-like droplets into the blastocoele (Plate 1) could represent the route of steroid transport. The trophoblast is able to store large amounts of lipid-like material which is released into the blastocoele at the mid- to late-blastocyst stages. In steroidogenic tissues, such as the zona fasiculata of the adrenal, lipid droplet sequestration and discharge appears to be the mechanism of release of steroids synthesized by the cell (Moses, Davis, Rosenthal \& Garren, 1969; Rhodin, 1971). The increasing number of lipid-like droplets in the trophoblast cell could represent the morphological basis for steroid movement across the rabbit trophectoderm after $135 \mathrm{~h}$ p.c.

Further studies are required to determine the possible roles of steroids in rabbit blastocysts during development. The data in this paper demonstrate that the presence of steroids in freshly collected blastocysts is insufficient evidence for steroidogenesis by the preimplantation embryo. Furthermore, the very high levels of progesterone, and sometimes of oestradiol, in rabbit uterine fluid probably indicate that steroids in the preimplantation rabbit embryo are entirely maternally derived.

We thank David Albertini for his assistance with the freeze-fracture technique, and John Biggers, Everett Anderson and Kenneth Ryan for their support of this research. The work was supported by Rockefeller Foundation Grants RF-72077 and RF-65040, and U.S. Public Health Service Grants 07923-03, 1 E22 HD 0310301 and 5 F22 HD 03103-02 from the NIH, and by the Program Project Grant 1 P01 HD-06916-01A1 from the NICHHD.

\section{References}

ANDERSON, W.A. \& ELLIS, R.A. (1965) Ultrastructure of Trypansoma lewisi: flagellum, microtubules and the kinetoplast. J. Protozool. 12, 483-499.

BeATO, M. \& BAIER, R. (1975) Binding of progesterone to the proteins of the uterine luminal fluid: identification of uteroglobin as the binding protein. Biochim. biophys. Acta 392, 346-356.

BeIER, H.M. \& MAURER, R.R. (1975) Uteroglobin and other proteins in rabbit blastocyst fluid after development in vivo and in vitro. Cell Tiss. Res. 159, 1-10.

Bhatт, B.M. \& Bullock, D.W. (1974) Binding of oestradiol to rabbit blastocysts and its possible role in implantation. J. Reprod. Fert. 39, 65-70.
Borland, R.M., Biggers, J.D. \& Lechene, C.P. (1976) Kinetic aspects of rabbit blastocoele fiuid accumulation. An application of electron probe microanalysis. Devl Biol. 50, 201-211.

Challis, J.R.G., Davies, I.J. \& Ryan, K.J. (1973) The concentrations of progesterone, estrone, and estradiol-17 $\beta$ in the plasma of pregnant rabbits. Endocrinology. 93, 971-976.

Challis, J.R.G., Davies, I.J., BenirschKe, K., Hendrickx, A.G. \& RYAN, K.J. (1975) The effects of dexamethasone on the peripheral plasma concentrations of androstenedione, testosterone, and cortisol in the pregnant rhesus monkey. Endocrino$\log y$ 96, 185-192. 
DickmanN, Z., DEY, S.K. \& Gupta, J.S. (1975) Steroidogenesis in rabbit preimplantation embryos. Proc. natn. Acad. Sci. U.S.A. 72, 298-300.

Ducibella, T., Albertini, D.F., Anderson, E. \& BigGers, J.D. (1975) The preimplantation mammalian embryo: characterization of intercellular junctions and their appearance during development. Devl Biol. 45, 231-250.

Fowler, R.E., Johnson, M.H., Walters, D.E. \& PRATT, H.P.M. (1976) The progesterone and protein composition of rabbit uterine flushings. $J$. Reprod. Fert. 46, 427-430.

Fuchs, A.R. \& Beling, C. (1974) Evidence for early ovarian recognition of blastocysts in rabbits. Endocrinology 95, 1054-1058.

Gulyas, B.J. \& KRISHNan, R.S. (1971) Current status of the chemistry and biology of "blastokinin". In The Biology of the Blastocyst, pp. 261-275. Ed. R. J. Blandau. University of Chicago Press.

Hafez, E.S.E. (1963) The uterotubal junction and the luminal fluid of the uterine tube in the rabbit. Anat. Rec. 145, 7-12.

Hamana, K. \& Hafez, E.S.E. (1970) Disc electrophoretic patterns of uteroglobin and serum proteins in rabbit blastocoele fluid. $J$. Reprod. Fert. 21, 555558.

Hastings, R.A. \& Enders, A.C. (1974) Uptake of exogenous protein by the preimplantation rabbit embryo. Anat. Rec. 179, 311-330.

Hastings, R.A. \& Enders, A.C. (1975) Junctional complexes in the preimplantation rabbit embryo. Anat. Rec. 181, 17-34.

HilliaRD, J. \& EATON, L.W. (1971) Estradiol-17ß, progesterone and 20 $\alpha$-hydroxypregn-4-en-3-one in rabbit ovarian venous plasma. II. From mating through implantation. Endocrinology 89, 522-527.

HUFF, R.L. \& EIK-NES, K.B. (1966) Metabolism in vitro of acetate and certain steroids by six-day old rabbit blastocysts. J. Reprod. Fert. 11, 57-63.

LuTWAK-MANN, C. (1971) The rabbit blastocyst and its environment: physiological and biochemical aspects. In The Biology of the Blastocyst, pp. 243-261. Ed. R. J. Blandau. University of Chicago Press.

Moses, H., Davis, W., Rosenthal, A. \& Garren, L. (1969) Adrenal cholesterol: localization by electron microscope autoradiography. Science, N.Y. 163, 1203-1205.

Rahman, S.S.U., Velayo, N., DomRes, P. \& Billiar, R.B. (1975) Evaluation of progesterone binding to uteroglobin. Fert. Steril. 26, 991-995.

RHodin, J.A.G. (1971) The ultrastructure of the adrenal cortex of the rat under normal and experimental conditions. J. Ultrastruct. Res. 34, 23-71.

SATo, I. (1958) A modified method for lead staining of thin sections. J. Electron Microsc. 17, 158-159.

Seamark, R.F. \& LuTwak-ManN, C. (1972) Progestins in rabbit blastocysts. J. Reprod. Fert. 29, 147-148.

Watson, M.L. (1958) Staining of tissue sections for electron microscopy with heavy metals. J. biophys. biochem. Cytol. 4, 475-495.

Received 28 June 1976 